\title{
The Relationship of Teacher Perceptions about Principal's Leadership and Work Motivation with Teacher Performance
}

\author{
Nofi Nofrial1 ${ }^{*}$, Nurhasan Syah ${ }^{2}$ Wawan Purwanto ${ }^{3}$
}

1,2,3 Fakultas Teknik, Universitas Negeri Padang

A R T I C L E I N F O

Article history:

Received 15 May 2019

Received in revised

form

29 June 2019

Accepted 18 July 2019

Available online 29

August 2019

Keywords:

Teachers' Perceptions

About Principal's

Leadership, Work

Motivation, Teacher

Performance

\begin{abstract}
A B S T R A C T
The aim to reveal and describe: Firstly The relationship between teachers' perceptions about principal's leadership with teacher performance, Secondly The relationship between work motivation and the teacher performance, Lastly The relationship between teachers' perceptions about the principals' leadership and work motivation together with the performance. This research uses a quantitative method that is correlational, the population in this research was as many as 73 teachers of SMK N 2 Sungai Penuh. The sampling technique in this research uses random sampling. Data collection techniques using instruments in the form of a questionnaire. The data analysis technique was carried out using the correlational technique with the help of the SPSS 21 application to determine the relationship between variables both individually and together, and the results of the study show: Firstly there is a significant relationship between teachers' perceptions of school principal's leadership and teacher performance, Secondly there is a significant relationship between work motivation and teacher performance, Lastly there is a significant relationship between teachers' perceptions about the principal's leadership, and work motivation together with teacher performance.
\end{abstract}




\section{Introduction}

Education is a strategic step that needs to be done, and also is the most important thing and has a very important role in advancing the country and producing quality human resources, because increasing human resources is the best solution and way to further enhance progress country. Then in addition to producing good quality education, all the components contained therein must run well too, schools are a formal educational institution which has an important role in efforts to shape the quality of better education.

Vocational High School (SMK), SMK is a school that is devoted to producing human resources and workforce that has quality and is prepared to be ready to enter the workforce, in the Law on national education no 20 of 2003 explains that vocational education is a system education that is devoted to preparing students in certain fields to be ready to work and enter the workforce directly.

The teacher is one of many important factors or components that have a role for the advancement of education in school, because the teacher is a person who interacts and is directly involved with students during the learning process.

Based on preliminary observations made by researchers at SMK N 2 Sungai Penuh, it was found that the trend of the results of the National Examination of students at SMK Negeri 2 Sungai Penuh which showed a decrease in the last few years, this can be seen in Table 1 :

Table 1. National examination results SMK N 2 Sungai Penuh

\begin{tabular}{cccc}
\hline No & School years & Number of participants & Average UN scores \\
\hline 1. & $2014-2015$ & 213 & 61,40 \\
2. & $2015-2016$ & 196 & 68,48 \\
3. & $2016-2017$ & 209 & 48,47 \\
4. & $2017-2018$ & 224 & 36,85 \\
\hline
\end{tabular}

The data in Table 1 shows that the National Exam scores of Students SMKN 2 Sungai Penuh have decreased, even in the 2017-2018 teaching year the value of the National Examination has decreased significantly compared to previous years, other than the student's own factor, wrong one thing that greatly contributes to the high or low scores of students as well as the success or failure of students in taking exams is the role of the teacher, the teacher not only has a role to teach students but also motivates, and directs that students are better prepared in facing the national exam, for that performance the teacher must be optimal in carrying out his work.

The teacher has an important role to shape the ability of students, the teacher's role is irreplaceable in the learning process. In accordance with Anies Baswedan's statement, "Although supported by complete educational facilities, a good curriculum, it does not necessarily guarantee quality education if there is no qualified teacher present" (Kompas, 2013). This shows that the teacher's role is very important in the educational process for that teacher must have a professional attitude when carrying out their duties, and teachers must show maximum performance.

Principal's leadership is one of the factors that can affect teacher performance. The school principal is a top leader in the school and is expected to be able to use his power and authority as a leader as well as possible for the achievement of educational goals, as the leader in the school the principal has a very important role as a motivator or as a motivator so that the existing teacher in schools have good performance, and also so that teachers are able to carry out the learning process optimally. Harahap and Rusdinal (2017) state that the success or failure of education in schools one of the indicators lies in the competency of the principal as manager (managerial competence), in addition to support from teachers, employees, parents, students, and the community and there are still many who the other. The principal also has an appropriate role with his authority, duties and responsibilities as a form of functional professional ability. With this professional ability, the principal is required to be able to carry out his role as an effective manager and leader.

Wahyudi (2009: 64) states that principals must have the right strategy for teachers and education staff to be able to cooperate or cooperate and continue to improve their abilities and profession, and encourage educational staff such as teachers to participate in activities that are to support school programs. The principal not only acts as a leader in the school, but also pays attention to how the teacher can successfully carry out his duties in teaching so that educational goals can be achieved.

Even though a principal has good managerial and supervisory skills, that alone will not be enough, the principal must also be able to create a good perception of himself, so that the principal must be able to 
establish a good relationship with the teacher and be able to create a working atmosphere comfortable and conducive so that the teacher has a good perception of his leadership. If the principal cannot make a good relationship with the teacher and cannot create a conducive working atmosphere then the teacher's perception will be bad about his leadership.

A teacher's perception about the principal's leadership is the teacher's view or opinion about the school principal's way of leading the school, whether it's a positive or negative view. Each teacher will have a different response or response about the leadership activities of a school principal, the response or response depends on how the teacher's assessment or perception in seeing how the head of school is in carrying out his leadership.

Based on observations and preliminary observations made at SMK N 2 Sungai Penuh found phenomena such as the lack of good relations and communication between the principal and several teachers, and also the principal tends to only involve a few teachers when doing an activity. Problems such as this can cause perceptions that are not good by the teacher of the leadership of the principal, so that it can cause an influence on teacher performance, and can be one of the factors causing poor teacher performance.

In addition to the teacher's perception of the principal's leadership, work motivation is one of the causes or factors that can affect teacher performance, a teacher has a high work motivation will have good performance and vice versa, teachers who have low work motivation will be low performance. Work motivation is a driving force that is in a person to do a certain activity in order to achieve a goal (Sardiman, 2012: 73). There are two types of motivation, namely intrinsic motivation and extrinsic motivation, intrinsic motivation is motivation that is formed from within a person without any encouragement or influence from others but on the basis of one's own desires. While extrinsic motivation is motivation or desire to do something because of outside encouragement or influence from others.

Based on the results of preliminary observations at SMK N 2 Sungai Penuh, and based on information and data obtained from the TU field every week there are always several teachers who come not on time with delays of up to 30 minutes for various reasons, and also when teaching hours are found the number of teachers entering and exiting is not according to the specified class hours, and there are still many teachers who have not prepared teaching materials such as making lesson plans (RPP) at the beginning of the semester, whereas RPP is very important to be used as a guide for teaching in every one meeting times and lesson plans are also very important for fluency in learning activities, this is clarified by the data obtained by researchers sourced from the deputy head of curriculum field of SMK N 2 Sungai Penuh that from a total of 73 teachers there were only 46 teachers $(63.01 \%)$ who submitted their lesson plans at the beginning of the semester while 27 teachers (36.99\%) had not yet submitting RPP at the beginning of semester 2019 .

The data above shows that there are still a number of problems with teacher performance such as teacher attendance and there are also teachers who have not submitted their lesson plans at the beginning of the semester even though this is a very important matter so if these problems if left unchecked can lead to no the achievement of the objectives of education, because the most important thing in the process of education and learning in schools is the performance of the teacher, besides that the role of the principal in leading also needs to be further improved both in managerial skills, conceptual, social, and technical skills, as well as the principal also demanded to be able to motivate all teachers and the ranks below to always work optimally in order to achieve educational goals.

The same research was conducted by Ari Wahyu in 2013 entitled "Study of the relationship between principals' leadership, professional competence, and work motivation of teachers on teacher performance in SMP Negeri 1 Bangli", and with the results of research that there is a significant relationship between leadership principals on teacher performance, there is a significant relationship between professional competence and teacher performance, there is a significant relationship between work motivation and teacher performance, and there is a significant relationship together between the principal's leadership, professional competence, and work motivation on teacher performance (Ari Wahyu, et al: 2013).

Finally, after looking at previous studies with the results that there is a significant relationship and influence between the leadership of the principal and work motivation on teacher performance, it is necessary to conduct this research to find out how much the relationship between the leadership of the principal and work motivation towards teacher performance, and in fact such research has never been carried out in SMK N 2 Sungai Penuh.

This study aims to reveal and describe: Firstly the relationship between teacher perceptions about the principals leadership with teacher performance, Secondly the relationship of work motivation with teacher performance in SMK N 2 Sungai Penuh, Lastly the relationship between teacher perception about principal leadership and work motivation together with teachers performance at SMK N 2 Sungai Penuh. 


\section{Methods}

This study uses a quantitative method that is correlational, the population in this study was as many as 73 teachers of SMK N 2 Sungai Penuh. The sampling technique in this study uses random sampling. Data collection techniques using instruments in the form of a questionnaire. The data analysis technique was carried out using the correlational technique with the help of the SPSS 21 application to determine the relationship between variables both individually and together.

To obtain data and results of the study carried out several stages: 1 . Test the validity and reliability of the instrument 2. Normality Test, Linearity Test, and Multicollinearity Test, 3 . Test the Correlation Analysis of Double and Double Regression.

\section{Result And Discussion}

The first hypothesis proposed is that there is a relationship between teachers perceptions about principals leadership and teacher performance, and based on the results of the analysis it is known that the correlation coefficient between principals' leadership and teacher performance is 0.416 . $R_{\text {count }}>R_{\text {table }}$ means that there is a relationship between leadership and teacher performance and the relationship is quite close. The analysis also shows that teacher perceptions about the leadership of school principals have a very high role on teacher performance.

The second hypothesis is that there is a relationship between work motivation and teacher performance, and based on the results of the analysis it is known that the correlation coefficient between work motivation and teacher performance is $0.906 . R_{\text {count }}>R_{\text {table }}$ means that there is a relationship between work motivation and teacher performance. Work motivation greatly determines the level of teacher performance, because with high work motivation, teacher performance will be better.

The third hypothesis that is proposed is that there is a relationship between teacher perceptions of school principal leadership, work motivation and teacher performance, and based on the results of the analysis it is known that the correlation coefficient between headmaster leadership, and work motivation

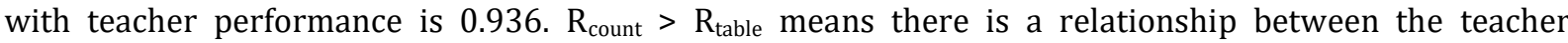
perceptions about principal's leadership, and work motivation with the teacher's performance and the relationship is very close.

\section{Conclussion}

There is a significant relationship between teachers' perceptions about the principal's leadership and teacher performance, obtained correlation coefficient rx1y $=0.416$, (2) There is a significant relationship between work motivation and teacher performance, obtained by the correlation coefficient rx2y $=0.906$, (3) There is a relationship which is significant between teachers 'perceptions of principals' leadership, and work motivation together with teacher performance with a correlation coefficient $\mathrm{rx} 1,2 \mathrm{y}=$ 0.936 .

\section{Reference}

Anonim. Undang-undang nomor 20 tahun 2003 tentang Sistem Pendidikan Nasional

Ari, W., dkk. (2013). Studi Hubungan antara Kepemimpinan Kepala Sekolah, Kompetensi Profesional, dan Motivasi Kerja Guru terhadap Kinerja Guru (e-journal).Singaraja: Universitas Pendidikan Ganesha.

Harahap, F dan Rusdinal, R. (2017). The influence of principal managerial competency toward teachers productivity with mediation of organizational citizenship behavior and interpersonal communication.In 2nd International Conference on Educational Management and Administration (CoEMA 2017).Atlantis Press.

Kompas. (2013). VIP-kan Guru-guru kita.Di akses Maret 1, 2019, dari https://edukasi.kompas.com/read/2013/11/28/1100170/VIP-kan.Guru-guru.Kita.

Wahyudi. (2009). Kepemimpinan Kepala Sekolah : Dalam Organisasi Pembelajaran (Learning Organization). Bandung: Alfabeta. 